\title{
PROSPECTS
}

\section{Backlash against multitasking}

\section{Scientists are increasingly asked to master skills in addition to their research. This is not necessarily a good thing, says Gene Russo.}

\author{
Four centuries after the \\ Renaissance, the halcyon \\ days of the polymath may \\ have returned - and some \\ budding scientists are not \\ pleased. Young investigators \\ might not be required \\ to emulate Leonardo da \\ Vinci, the epitome of the \\ Renaissance man, but
} scientists are urged more and more often - including in the pages of Naturejobs - to expand their skill sets to make themselves more marketable for research positions, and to bring them more in touch with the financial realities of today's science. Sometimes it seems that being good at the research itself is no longer enough, especially given the tight job market in some regions and sectors. This is not necessarily a good thing.

At a 1 July conference called 'Tomorrow's Giants', convened by the Royal Society in London as part of its 350th-anniversary celebrations and co-organized by Nature, postdocs from across the United Kingdom weighed in on the issues that they feel are most important to them and their future colleagues. Esteemed senior scientists and administrators listened in and offered their own views; UK science ministers, university chancellors and Nature's editor-in-chief were among the panellists. Several postdocs raised the topic of training, but they weren't calling for more - they wanted less. These young scientists argued that they had not steeped themselves in the movements of mitochondria, the make-up of molecules or the fundamental foundations of the Universe in the hope of learning how to 'expand their skill set'. Most work long hours at low pay so they can be scientists: investigators unveiling the mysteries of the natural world.

Yet they're often told that they must be much more. Career counsellors say that young researchers must also be good communicators, able to explain their work to the taxpayers who often indirectly fund it. It is true that the importance of that work must be made clear; researchers should fight any perception that they are tinkerers using public money simply to satisfy inconsequential curiosities. Ideally, scientists should have public-relations skills and be able to articulate clearly and concisely to the media how their findings - however basic or fundamental might one day make a difference to society. A little bit of salesmanship is not a bad idea. In a perfect world, they should also know how to manage a lab and delegate responsibilities efficiently.

So how might young

scientists face expectations and stay marketable?

Some commentators take a hard-line stance, as articulated at the Royal Society meeting by Adrian Smith, director-general of science and research at the UK Department for Business, Innovation and Skills. The reality, as he and others would have it, is that scientists must master multiple skill sets, in addition to research, to succeed. If they don't have both the scientific acumen and the ancillary soft skills, commentators say, their careers could suffer. Deal with it.

Others - including some postdocs at the Royal Society meeting - take a different view. They say that scientists should consider the benefits of a training course or two, but not neglect the science - ever. Researchers should concentrate first and foremost on their work, and not worry too much about management skills that may or may not end up being germane to their career. Distractions from the science increase the likelihood of failing to finish a project and acquire muchneeded publication credentials. After all, researchers are passionate about their science, not about media training. The future will need people who can do science, not just those who can sell it, say these 'purists'.

There is a third option, or perhaps a corollary to the above, that was suggested at a session of the biennial EuroScience Open Forum meeting in Turin, Italy, in early July. Gerhard Wolf, a member of the European Union's Economic and Social Committee, proposed that scientists who are, say, not gifted communicators should consider eschewing the frustrating pursuit of such soft skills. Instead, he argues, they should find a research team that includes a good communicator, a team in which their scientific talents complement those of other members.

This makes sense, especially in this age of interdisciplinary team science. There is plenty of room for the Renaissance men or women, the capable scientists who can see the big picture, communicate that vision to the layperson, and run a lab like a small business. But the specialists, the scientists with a laser focus on their discipline of choice, also have a crucial role. Tomorrow's giants will have multiple forms, not just multiple tasks.

Gene Russo is the editor of Naturejobs. $\triangle N$ BRIEF

Largest EU science budget

Up to 110,000 science research posts will be created at 16,000 universities, research institutions and companies as part of a $€ 6.4$-billion (US\$8.25-billion) investment by the European Commission (EC), says Mark English, EC spokesman for research, innovation and science. The 2011 budget - the largest ever for EC research and up $12 \%$ from 2010 - will help to lift Europe's economy by speeding discoveries into the market, said Máire Geoghegan-Quinn, commissioner for research, innovation and science, on 19 July. The funds will largely support research into climate change, food security and health. Innovation is the best way to create "good jobs that will withstand globalization", said the commissioner.

\section{Women's health grants}

The US National Institutes of Health has awarded about $\$ 6$ million in grants to 12 US universities and medical centres in the fifth funding round of a career-development programme in women's health research. Up to 60 junior researchers will take part in the Building Interdisciplinary Research Careers in Women's Health programme, as principal investigators can select up to five juniorlevel researchers from their institution or others. Some 378 early-career scientists have participated in the development programme, which launched in 2000 , and many have since written their own grant applications. "This is a step to independence," says Joyce Rudick, NIH director of programmes and management.

\section{Happier male academics}

Among untenured biological and physical sciences faculty members in the United States, men and women report marked differences in job satisfaction, according to a 12 July report by Harvard University's Collaborative on Academic Careers in Higher Education. In both disciplines, men are happier than women about the time allotted for research, and the compatibility of working for tenure while raising a family. In biological sciences, men are more content with their teaching responsibilities and work-life balance; in physical sciences, men are happier with their opportunities to collaborate with tenured faculty members. Men are generally more satisfied across all academic areas, and physical sciences faculty members are happier than those in any other field. 